\title{
In vitro degradability of coffee husks treated with doses of fibrolytic enzymes for use in ruminant nutrition
}

\section{Avaliação da degradabilidade in vitro da casca de café tratada com doses de enzimas fibrolíticas para aproveitamento na alimentação de ruminantes}

\author{
Yasmin Haluan Porto Moura ${ }^{1 *}$; Carmen Lucia de Souza Rech ${ }^{2}$; Mauro Pereira de \\ Figueiredo ${ }^{3}$; José Luiz Rech"; Yann dos Santos Luz; ; Jennifer Souza Figueredo ${ }^{6}$; \\ Alex Aguiar Figueiredo ${ }^{7}$
}

\begin{abstract}
The agricultural activity has generated a progressive amount of waste, which needs a proper treatment to avoid negative environmental impacts. At the same time, values can be added to such waste, as its use in animal feed. This research was conducted at the laboratory of Animal Nutrition, State University of Southwestern Bahia, campuses of Vitória da Conquista and Itapetinga. The objective of this study was to evaluate the effect of coffee husks on ruminant feeds by increasing doses of fibrolytic enzymes, evaluating their effects on in vitro ruminal degradability of dry matter (DM), neutral detergent fiber (NDF), and acid detergent fiber (FDA) of the coffee husk (CH). The experiment was a completely randomized design in a $2 \times 4$ factorial scheme. It compounded the following treatments: Coffee husk (CH1): 1.5\% enzymes (E) and $24 \mathrm{~h}$ enzymatic action (EA); $\mathrm{CH} 2: 3.0 \%$ (E) and 24h (EA); $\mathrm{CH} 3: 4.5 \%$ (E) and $24 \mathrm{~h}(\mathrm{EA})$; CH4: 6\% (E) and $24 \mathrm{~h}$ (EA); CH5: 1.5\% (E) $48 \mathrm{~h}$ (EA); CH6: 3\% (E) and 48h (EA); $\mathrm{CH} 7: 4.5 \%$ (E) and 48h (EA); and CH8: 6\% (E) and $48 \mathrm{~h}$ (EA), all based on dry matter. An improvement in the degradability of the nutritional parameters MS, NDF, and FDA occurred with the addition of enzymes, with $3 \%$ enzyme addition being the best level, and 24 hours, as the best action time. In addition to that, as the EA on coffee husk increased, the degradation rate decreased. Therefore, the use of enzymes can improve the digestibility of the fibrous fraction, enabling the use of the coffee husk and possibly other agroindustrial residues, thus minimizing their adverse effects on nature.
\end{abstract}

Key words: Animal feed. Ruminal degradation. Cellulase enzymes. Hemicellulases.

1 M.e em Ciências Ambientais, Discente de Doutorado em Zootecnia, Universidade Estadual do Sudoeste da Bahia, UESB, Campus Itapetinga, BA, Brasil. E-mail: yasminphaluan@hotnail.com

2 Dr $^{\mathrm{a}}$ em Zootecnia, Prof ${ }^{\mathrm{a}}$ Titular, Departamento de Tecnologia Rural e Animal, UESB, Campus Itapetinga, BA, Brasil. E-mail: jlclrech@uol.com.br

3 Dr. em Zootecnia, Prof. Pleno, Departamento de Fitotecnia e Zootecnia, UESB, Campus Vitória da Conquista, BA, Brasil. E-mail: mfigue2@uesb.edu.br

4 Dr. em Zootecnia, Prof. Adjunto, Departamento de Tecnologia Rural e Animal, UESB, Campus Itapetinga, BA, Brasil. E-mail: jlrech@uol.com.br

5 M.e em Zootecnia, Discente de Doutorado em Zootecnia, UESB, Campus Itapetinga, BA, Brasil. E-mail: yann_agronomia@ yahoo.com.br

6 Eng $^{\mathrm{a}}$ Agr ${ }^{\mathrm{a}}$, Discente de Mestrado em Zootecnia, UESB, Campus Itapetinga, BA, Brasil. E-mail: laurela4@hotmail.com

7 Zootecnista, UESB, Campus Itapetinga, BA, Brasil. E-mail: alexaf_zootecnista@hotmail.com

* Author for correspondence

Received: Oct. 20, 2016 Approved: June 06, 2017 


\section{Resumo}

A atividade agrícola tem gerado uma quantidade progressiva de resíduos, os quais necessitam serem tratados de forma adequada para que não promovam impactos ambientais negativos e que, ao mesmo tempo, sejam agregados valores a estes para que possam ser utilizados na alimentação animal. A pesquisa foi conduzida no laboratório de Nutrição Animal da Universidade Estadual do Sudoeste da Bahia, campus de Vitória da Conquista e Itapetinga. Objetivou-se o aproveitamento da casca de café na alimentação de ruminantes através do tratamento com doses crescentes de enzimas fibrolíticas avaliando seus efeitos sobre a degradabilidade ruminal in vitro da matéria seca (MS), fibra em detergente neutro (FDN) e fibra em detergente ácido (FDA) da casca de café (CC). O delineamento experimental utilizado foi inteiramente casualisado, com esquema fatorial $2 \times 4$, constituindo os seguintes tratamentos Casca de café (CC1): 1,5\% de Enzimas (E) e 24h de Ação Enzimática (AE); CC2: 3\% (E) e 24h (AE); CC3: 4,5\%(E) e $24 \mathrm{~h}(\mathrm{AE}) ; \mathrm{CC} 4: 6 \%$ (E) e $24 \mathrm{~h}(\mathrm{AE}) ; \mathrm{CC} 5: 1,5 \%$ (E) $48 \mathrm{~h}(\mathrm{AE}) ; \mathrm{CC} 6: 3 \%$ (E) e 48h(AE); $\mathrm{CC} 7: 4,5 \%$ (E) e 48h(AE); CC8: 6\% (E) e $48 \mathrm{~h}(\mathrm{AE})$, com base na matéria seca. Constatou-se que com adição de enzimas, ocorreu uma melhora na degradabilidade dos parâmetros nutricionais MS, FDN e FDA, sendo $3 \%$ de enzimas o melhor nível e 24 horas o melhor tempo de ação. Além disso, à medida que a ação enzimática na casca de café aumentou, a taxa de degradação diminuiu. Portanto, o uso de enzimas pode melhorar a digestibilidade da fração fibrosa, possibilitando o uso da casca de café e possivelmente outros resíduos agroindustriais, minimizando assim seus efeitos adversos sobre a natureza.

Palavras-chave: Alimentação animal. Degradação ruminal. Enzimas celulases e hemicelulases.

\section{Introduction}

With industrialization, Brazil has shown a marked increase in agricultural and agroindustrial activities, consequently generating a large amount of residues (SANTOS et al., 2012), which often compromise water and soil (MATOS et al., 2006, 2007; RIGUEIRA et al., 2010; SANTOS et al., 2012).

According to Conab (2014), Brazil produced about 45.14 million coffee bags in 2014. The husk constitutes the first residue and represents about $39 \%$ of the fruit fresh mass, or $29 \%$ of the fruit dry mass (MATOS, 2008). There is a great availability of coffee husks in Brazil, as the country is the largest coffee producer and exporter.

Nutrition is a crucial factor for the success of confined cattle production since feed costs have a great impact on the total activity cost (LOPES et al., 2011). In face of this impasse, the use of agroindustrial residues in animal feed would be a promising alternative both socioeconomically and environmentally (NUNES et al., 2007). The coffee husk is one of the most evaluated agricultural residues in ruminant feed (ROCHA et al., 2006).
However, it has chemical compounds which negatively affect its nutritional value (MALTA et al., 2013), such as the presence of phenolic compounds (SOUZA et al., 2006). Additionally, this residue has high fiber content, which limits animal consumption and digestibility (MENDES et al., 2014).

Three pieces of technical information are necessary for the calculation to make a ration: the animal nutritional requirements, the feed chemical composition, and its degradability (RECH et al., 2010). The method of in vitro degradability is simpler and more economical to obtain the feed digestibility and aims to mimic the fermentation of rumen-reticulum using rumen liquid and/or fibrolytic enzymes. The technique has applications and advantages, such as the determination of digestion rate and digestion extension, which is related to digestibility and affects the passage rate and consumption (LANA, 2007).

The use of exogenous fibrolytic enzymes (cellulase and hemicelluloses) arises with the aim of increasing the efficiency of feed use by ruminants. These enzymes potentiate the degradation of structural polysaccharides, together with the 
enzymes produced by rumen microorganisms, increasing the fiber degradation rate (MARTINS et al., 2007).

The objective of this study was to evaluate the effect of exogenous fibrolytic enzymes on the in vitro ruminal degradability of coffee husks to evaluate their possible use in ruminant feed.

\section{Material and Methods}

The experiment and the chemical and bromatological analyses were carried out at the Laboratory of Animal Nutrition of the State University of the Southwest of Bahia - UESB, campuses in Vitória da Conquista and in Itapetinga - BA, Brazil.

A completely randomized design (CRD) was used in a $2 \times 4$ factorial scheme, with two enzyme action times (24h and $48 \mathrm{~h}$ ), and four enzyme doses $(1.5,3,4.5$, and $6 \%)$. The treatments were: coffee husk $(\mathrm{CH} 1)$ : $1.5 \%$ enzymes, $24 \mathrm{~h}$ and $48 \mathrm{~h}$ enzymatic action; $\mathrm{CH} 2: 3 \%$ enzymes, $24 \mathrm{~h}$ and $48 \mathrm{~h}$ enzymatic action; $\mathrm{CH} 3: 4.5 \%$ enzymes, $24 \mathrm{~h}$ and 48h enzymatic action; $\mathrm{CH} 4: 6 \%$ enzymes, $24 \mathrm{~h}$ and $48 \mathrm{~h}$ enzymatic action, based on dry matter, totaling 8 treatments with three replicates each. The data were submitted to analysis of variance, and means were compared by the Tukey Test $(\mathrm{P}<0.05)$ for the evaluation of time effect. Regression was used to evaluate the effects of the increase of enzyme doses on the variables/response. A differential factorial scheme (factorial with a control treatment) was performed, and data were submitted to analysis of variance. The statistical software SAS - Statistical Analyses System (SAS, 2002) and Assistat version 7.7 (SILVA; AZEVEDO, 2016) were used. The mean values of the potentially degradable fraction "b" and potential degradability "PD" (DM), and those of the "b" and "c" fraction degradation rate (NDF and ADF) were converted by the formula $-2 \sqrt{x}$ to obtain data normality, thus maintaining the original means.
The coffee husk used was purchased from Cooperativa Mista Agropecuária Conquistense COOPMAC and the exogenous fibrolytic enzymes (commercial product: Novozymes Latin America Inc.: cellulose - NS 50013 and hemicellulose - NS 22022) were acquired through a donation made by the manufacturer.

Two hundred and fifty grams of coffee husk natural matter (NM) were used per experimental unit, using the following enzyme amounts: $2,40 \mathrm{~mL}$; $4.80 \mathrm{~mL} ; 7.20 \mathrm{~mL} ; 9.60 \mathrm{~mL}$, which correspond to the dosages $1.5,3.0,4.5$, and $6.0 \%$ enzymes on the dry basis, respectively. These were diluted in distilled water $\left(100 \mathrm{~mL} \mathrm{~kg}^{-1} \mathrm{DM}\right)$ in the proportion of $50 \%$ cellulase and 50\% hemicellulose, and subsequently, the solutions were sprinkled on the coffee husk and homogenized. Then the coffee husk was taken to the forced circulation air oven, set at $45{ }^{\circ} \mathrm{C}$ for better enzymatic action. After the end of the $24 \mathrm{~h}$ and $48 \mathrm{~h}$ of trials, samples were frozen to cease enzymatic activity and later removed from the freezer and ground in a sifted mill with sieves of $1 \mathrm{~mm}$ in diameter.

An aliquot of the coffee husk sample was taken in the natural form, and also from those inoculated with exogenous fibrolytic enzymes for bromatological determinations: dry matter (DM), crude protein (CP), neutral detergent fiber (NDF), acid detergent fiber (ADF), cellulose (CEL), hemicellulose (HEM), lignin (LIG), ethereal extract (EE), and ashes (MM), according to the methodology described by Rech et al. (2010).

The methodology described by Yoshioka et al. (1981) and Miller (1959) was used to evaluate fibrolytic enzyme activity. The quantifications of the reducing sugars of recovered extracts represent enzyme activities, being 51 and $28 \mathrm{mg} \mathrm{mL}^{-1}$ for cellulases and hemicellulases respectively, showing enzyme effectiveness.

The ruminal liquid collected was from a Dutch cow, cannulated in the rumen, with a mean live weight of $500 \mathrm{~kg}$, maintained on pasture with 
Brachiaria decumbens with additional $2 \mathrm{~kg}$ of coffee husk in the trough for a period of 15 days to adapt to the feed before collection. The liquid collected was placed in thermal bottles. The buffer solution was prepared in containers and preheated to $39^{\circ} \mathrm{C}$ before being added to the ruminal liquid. The solution A ( $g$ $\mathrm{L}^{-1}$ ) was composed of $10.0 \mathrm{~g} \mathrm{KH}_{2} \mathrm{PO}_{4} ; 0.5 \mathrm{~g} \mathrm{MgSO}_{4}$ $7 \mathrm{H}_{2} \mathrm{O} ; 0.5 \mathrm{~g} \mathrm{NaCl} ; 0.1 \mathrm{~g} \mathrm{CaCl}_{2} 2 \mathrm{H}_{2} \mathrm{O}$ and $0.5 \mathrm{~g}$ urea. Solution B $\left(\mathrm{g} \mathrm{L}^{-1}\right)$ was made of $15.0 \mathrm{~g} \mathrm{Na}_{2} \mathrm{CO}_{3}$; $1.0 \mathrm{~g} \mathrm{Na} \mathrm{Na}_{2} \mathrm{~S} .9 \mathrm{H}_{2} \mathrm{O}$. The solutions were mixed by adding about $266 \mathrm{~mL}$ of solution $\mathrm{B}$ to $1330 \mathrm{~mL}$ of solution $\mathrm{A}$ (1:5 ratio), $\mathrm{pH}$ was maintained at 6.8 , and temperature at $39^{\circ} \mathrm{C}$.

The determination of in vitro ruminal degradability of the coffee husk DM, NDF, and ADF was performed according to the ANKOM ${ }^{\mathrm{TM}}$ methodology (ANKOM TECHNOLOGY, 2010), adapted to the artificial rumen, using the TE150 (TECNAL) incubator. An aliquot of $0.5 \mathrm{~g}$ dried sample was weighed into filter bags (F-57 $\mathrm{ANKOM}^{\mathrm{TM}}$ ), which were then sealed using a blade sealer. The bags were placed in six incubation jars, with 25 samples per jar. Each jar corresponds to one of the incubation times, being 0 (directly washed), $6,24,48,96$, and $120 \mathrm{~h}$.

After the incubation period, the filter bags were removed and washed in running water until completely whitened for approximately $5 \mathrm{~min}$. After washing, all bags were placed in forced ventilation oven $\left(65^{\circ} \mathrm{C}\right.$ for $\left.48 \mathrm{~h}\right)$ to dry, and then in an oven at $105{ }^{\circ} \mathrm{C}$ for $4 \mathrm{~h}$. Then, they were removed and stored in a desiccator, and afterwards weighed.

The determination of the NDF degradation was carried out according to the $\mathrm{ANKOM}^{\mathrm{TM}}$ methodology (ANKOM TECHNOLOGY, 2010), using the TE-149 fiber determination apparatus (TECNAL). After digestion in neutral detergent, at $100^{\circ} \mathrm{C}$ for $1 \mathrm{~h}$, the filter bags were washed in hot water four times for $5 \mathrm{~min}$, and in acetone for $3 \mathrm{~min}$. After this procedure, the bags were dried in a forced ventilation oven $\left(65^{\circ} \mathrm{C}\right.$ for $\left.48 \mathrm{~h}\right)$, and in an oven at $105^{\circ} \mathrm{C}$ for $4 \mathrm{~h}$, then removed, stored in a desiccator, and weighed.

Estimates of the degraded fraction of DM and NDF were obtained by the difference in weight found between weighing before and after artificial rumen incubation and neutral detergent extraction, expressed as a percentage.

The model of Orskov and McDonald (1979) was used to estimate the potential degradability of DM and the parameters of coffee husk ruminal degradability, according to the formula: $p=a+b(1$ and ec*t), in which "p" is potential degradability; "a" water-soluble fraction; "b" potentially degradable fraction; "c" fraction degradation rate " $b$ " (h-1), and " t", incubation time (h).

The model of Mertens and Loften (1980) was used to estimate the fibrous fraction (NDF and $\mathrm{ADF})$, according to the formula: $\hat{\mathrm{Y}}=\mathrm{b} \times \mathrm{e}^{(-\mathrm{cx}(\mathrm{T}-\mathrm{L}))}$ + Ind, $\hat{Y}=\mathrm{b}+\mathrm{I}$ when $0<\mathrm{t}<\mathrm{L}$, in which " $\mathrm{Y}$ " is the non-degradable residue over time $\mathrm{T}$; " $\mathrm{b}$ " the potentially degradable fiber fraction (over time $\mathrm{t} \leq$ $\mathrm{L}, \mathrm{b}=\hat{\mathrm{Y}}-\mathrm{I})$; "c" is the degradation rate of $\mathrm{b}(\mathrm{h}-1)$; " $T$ " is the incubation period in hours; " $L$ " latency or incubation time (h); and "I" the indigestible fiber fraction.

The coffee husk effective degradability was calculated by the formula $\mathrm{p}=\mathrm{a}+[(\mathrm{b} \times \mathrm{c}) /(\mathrm{c}+\mathrm{k}) \times \mathrm{e}-$ $(\mathrm{c}+\mathrm{k}) \times \mathrm{L}]$ : in which " $\mathrm{k}$ " is the rate of passage (McDONALD, 1981). Passage rates of $2 \%$, $5 \%$, and $8 \%$ were used to calculate the effective degradability.

\section{Results and Discussion}

The results of the degradability parameters of in vitro dry matter were affected $(\mathrm{P}<0.05)$ by the interaction between enzymatic action times and enzyme levels only for potential degradability "PD" and the potentially degradable fraction "b" (Table 1). 
Table 1. Mean parameters of in vitro ruminal degradability of coffee husk dry matter.

\begin{tabular}{|c|c|c|c|c|c|c|c|c|c|}
\hline \multirow{2}{*}{$\begin{array}{c}\text { ENZYME } \\
\text { ACTION } \\
\text { TIME } \\
\end{array}$} & \multicolumn{5}{|c|}{ ENZYMES } & \multirow[b]{2}{*}{ MEAN } & \multirow[b]{2}{*}{ CV (\%) } & \multirow[b]{2}{*}{ EQUATION } & \multirow[b]{2}{*}{$\mathbf{R}^{2}$} \\
\hline & $\mathbf{T}$ & 1.5 & 3.0 & 4.5 & 6.0 & & & & \\
\hline & \multicolumn{9}{|c|}{$\mathbf{a}^{1}(\%)$} \\
\hline 24 & \multirow{3}{*}{30.8} & 31.3 & 33.2 & 32.6 & 31.9 & $32.3 \mathrm{a}$ & \multirow{3}{*}{3.89} & \multirow{3}{*}{$\begin{array}{c}y=26.66+2.08 x- \\
0.24 x^{2}\end{array}$} & \multirow{3}{*}{0.92} \\
\hline 48 & & $27.3^{*}$ & 27.6 & 30.2 & 29.0 & $28.5 \mathrm{~b}$ & & & \\
\hline \multirow[t]{2}{*}{ Mean } & & 29.3 & 30.5 & 31.5 & 30.5 & 30.44 & & & \\
\hline & \multicolumn{9}{|c|}{$\mathbf{b}^{2}(\%)$} \\
\hline 24 & \multirow{2}{*}{45.5} & $44.0 \mathrm{a}$ & $46.9 a$ & $42.4 \mathrm{a}$ & $42.1 b^{*}$ & - & \multirow{2}{*}{1.92} & \multirow{2}{*}{ NS } & \multirow{2}{*}{-} \\
\hline 48 & & $45.0 \mathrm{a}$ & $42.6 b$ & $43.0 \mathrm{a}$ & $45.1 \mathrm{a}$ & - & & & \\
\hline & \multicolumn{9}{|c|}{$\mathrm{C}^{3}(\% . h)$} \\
\hline 24 & & 0.04 & 0.03 & 0.04 & 0.03 & $0.04 \mathrm{a}$ & \multirow{3}{*}{20.38} & \multirow{3}{*}{ NS } & \multirow{3}{*}{-} \\
\hline 48 & 0.04 & 0.04 & 0.03 & 0.03 & 0.02 & $0.03 a$ & & & \\
\hline \multirow[t]{2}{*}{ Mean } & & 0.04 & 0.03 & 0.04 & 0.03 & 0.04 & & & \\
\hline & \multicolumn{9}{|c|}{ PD $(\%)$} \\
\hline 24 & \multirow{2}{*}{77.4} & $75.3 \mathrm{a}$ & $80.2 \mathrm{a}$ & $75.0 \mathrm{a}$ & $73.9 \mathrm{a}$ & - & \multirow{2}{*}{1.82} & \multirow{2}{*}{$\begin{array}{c}y=0.12+ \\
0.00000619 x\end{array}$} & \multirow{2}{*}{0.001} \\
\hline \multirow[t]{2}{*}{48} & & $72.4 \mathrm{a}$ & $70.3 b^{*}$ & $73.2 \mathrm{a}$ & $74.1 \mathrm{a}$ & - & & & \\
\hline & \multicolumn{9}{|c|}{ ED $^{4} 2 \% . h^{-1}(\%)$} \\
\hline 24 & \multirow{3}{*}{62.65} & 61.8 & 63.3 & 62.0 & 59.3 & $61.6 \mathrm{a}$ & & & \\
\hline 48 & & 57.9 & $55.3^{*}$ & 58.2 & $55.1^{*}$ & $56.6 \mathrm{~b}$ & 2.69 & $y=60.93-0.48 x$ & 0.49 \\
\hline Mean & & 59.9 & 59.3 & 60.1 & 57.1 & 59.1 & & & \\
\hline & & & & & $\mathrm{ED}^{4} 5 \%$ & $h^{-1}(\%)$ & & & \\
\hline 24 & & 52.3 & 52.9 & 52.7 & 49.8 & $52.0 \mathrm{a}$ & & & \\
\hline 48 & 52.45 & 48.0 & $45.8^{*}$ & 48.5 & $45.0^{*}$ & $46.8 b$ & 3.54 & $y=51.15-0.46 x$ & 0.39 \\
\hline Mean & & 50.2 & 49.3 & 50.6 & 47.4 & 49.4 & & & \\
\hline & & & & & $E^{4} 8^{\circ}$ & $h^{-1}(\%)$ & & & \\
\hline 24 & & 47.4 & 47.9 & 47.9 & 45.2 & $47.2 \mathrm{a}$ & & & \\
\hline 48 & 47.2 & 42.9 & $41.1^{*}$ & 43.8 & $40.6^{*}$ & $42.2 \mathrm{~b}$ & 3.69 & $10.3 \mathrm{x}+3.3 \mathrm{x}^{2}-$ & 0.99 \\
\hline Mean & & 45.2 & 44.6 & 45.9 & 43.0 & 44.7 & & & \\
\hline
\end{tabular}

${ }^{1}$ Soluble fraction; ${ }^{2}$ potentially degradable fraction; ${ }^{3}$ fraction b degradation rate; ${ }^{4}$ potential degradability, ${ }^{5}$ effective degradability. Means of enzymatic action times, followed by the same lowercase letter in the same column do not differ by the F-test at $5 \%$ probability. Means followed by * differ from the control (material without enzymatic treatment) by the Dunnett test at $5 \%$ probability.

A decrease from $32.3 \%$ to $28.58 \%(\mathrm{P}<0.05)$ was observed with the increase of enzyme action time for the values of fraction "a" (soluble fraction). A long-term exposure to heating might have caused complexation of the soluble sugars from enzyme actions. In terms of enzyme levels, a quadratic effect was observed for the fraction "a", whose maximum point is $4.3 \%$ enzyme addition.
Fraction "b" (potentially degradable fraction) results showed interaction $(\mathrm{P}<0.05)$ between enzyme levels and enzymatic action times, with significant differences between times $24 \mathrm{~h}$ and $48 \mathrm{~h}$ for doses of 3 and $6 \%$ enzymes. Higher values of this fraction were observed in $24 \mathrm{~h}$ for $3 \%$ enzymes. This event was verified in $48 \mathrm{~h}$ for $6 \%$. Enzyme levels had no effect on times $24 \mathrm{~h}$ and $48 \mathrm{~h}$. 
The range of "c" fraction values vest important differences in the feeds since it results in greater or smaller carbohydrate digestibility, because the "c" fraction reflects effect in the ruminal repletion, resulting in less energy availability due to its characteristic of indigestibility, promoting lower potential consumption per time unit (VAN SOEST, 1994).

There was no difference $(\mathrm{P}>0.05)$ between times for coefficient "c" (fraction b degradation rate), and no significant effects were observed for enzyme levels.

The values of the "c" content (degradation rate) found in this study were 0.04 and $0.03 \% / \mathrm{h}$ in the enzymatic action times of 24 and 48 hours respectively, similar to those found by Oliveira (2011), with values of 0.02 and $0.03 \% / \mathrm{h}$, working with sugarcane bagasse treated with urea and fibrolytic enzymes. The results were higher than were those found by Andrade (2015) when ammonizing cotton residue, obtaining an average of $0.016,0.018$, and 0.029 , for 4,6 , and $8 \%$ of urea.

Krueger et al. (2008), when working with fibrolytic enzymes (Biocellulase A20) and $\mathrm{NH}_{3}$ in Bermuda grass hay, reported that the "c" degradation rate was not affected, with values of $4.75 ; 5.14 ; 4.27 ; 3.84$, and $4.09 \% \mathrm{~h}^{-1}$ for the control, $\mathrm{NH}_{3}$, enzymes applied after cutting, at baling, and at the animal feeding moment, respectively.

The interaction between the factors time and enzymatic action $(\mathrm{P}<0.05)$ could be seen for potential degradability, with a significant difference between times for 3\% enzyme level, and $24 \mathrm{~h}$ was superior to $48 \mathrm{~h}$. Enzymes showed a linear increasing effect, in which with every $1 \%$ of enzymes added, the degradation rate of this fraction increased by $6.19 .10^{-6}$ percentage units.

There was a difference $(\mathrm{P}<0.05)$ between the enzymatic action times $24 \mathrm{~h}$ and $48 \mathrm{~h}$ for effective degradability at 2,5 , and $8 \% \mathrm{~h}^{-1}$, reducing the degradation of these fractions from 61.6 to 56.6; 52.0 to 46.9 , and from 47.2 to 42.2 over time. As for enzyme levels, linear decreasing effects were observed $(\mathrm{P}<0.05)$ for the "ED" fractions at 2 and $5 \% \mathrm{~h}^{-1}$, and each $1 \%$ enzymes decreased 0.48 and 0.46 degradation rate percentage units of effective degradability at $2 \%$, and effective degradability at $5 \% \mathrm{~h}^{-1}$, respectively. The treatment with fibrolytic enzyme levels had a cubic effect for the "ED" fraction at $8 \%$. Moreover, a maximum enzyme action was obtained at $4.59 \%$, and a minimum of $6 \%$ at times $24 \mathrm{~h}$ and $48 \mathrm{~h}$.

In the comparison test with the control in the DM parameter, for the soluble fraction (a) only the $1.5 \%$ enzyme level at time $48 \mathrm{~h}$ differed $(\mathrm{P}<0.05)$ from the control. For the potentially degradable fraction (b), the $6 \%$ enzyme level at time $24 \mathrm{~h}$ differed $(\mathrm{P}<0.05)$ from the control. For the fraction degradation $\mathrm{b}(\mathrm{c})$ there were no differences $(\mathrm{P}<0.05)$ between the control treatment and the others. As for potential degradability (PD), only the treatment of $3 \%$ enzymes at time $48 \mathrm{~h}$ differed from the control $(\mathrm{P}<0.05)$.

For effective degradability at 2,5 , and $8 \% \mathrm{~h}^{-1}$ (ED 2, 5, 8\%), the differences $(\mathrm{P}<0.05)$ compared to the control were observed in the treatments of 3 and $6 \%$ enzymes at time $48 \mathrm{~h}$.

Figure 1 shows an increase in DM degradability in the enzymatic level at $3 \%$, at time $24 \mathrm{~h}$. The adding of $3.5 \%$ enzyme caused a reduction in NDF content, which provided a higher degradable DM content, highlighting the addition of $3 \%$ in comparison to the others (unpublished data).

Alvarez et al. (2009), when working with the application of enzymes onto oat straw and wheat bran, observed that enzymes increased the soluble fraction of the treated material (a), but no effects were detected in the potentially digestible fraction (b), "b" fraction degradation rate (c), and potential degradability $(a+b)$. They also reported a greater DM degradation when enzymes were preincubated with the roughage. Martins et al. (2008) referred to an interaction $(p<0.05)$ between the roughage source (rice straw and corn silage) and enzyme addition 
for both soluble (a) and potentially degradable (b) the roughage with the addition of enzymes $(p<0.05)$ fractions, with a reduction of the DM ' $b$ ' fraction of as a consequence of the soluble fraction increase.

Figure 1. Diagram of in vitro ruminal fermentation kinetics of coffee husk dry matter treated with exogenous fibrolytic enzymes.

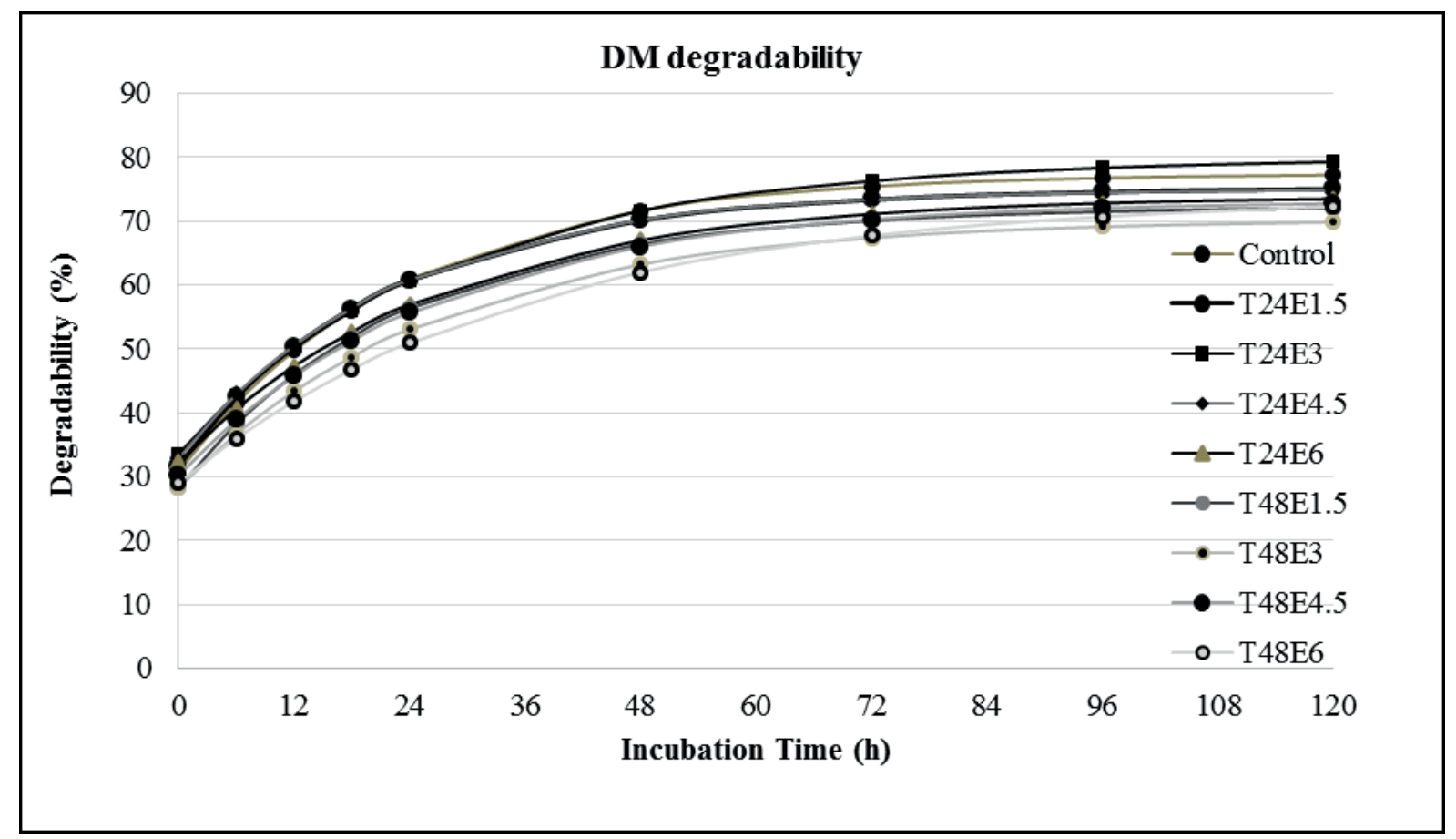

However, in the present study enzymes had an effect $(\mathrm{P}<0.05)$ on almost all the parameters of ruminal degradation of $\mathrm{DM}$ and $\mathrm{CH}$, with the interaction between enzyme levels and time $(24 \mathrm{~h}$ and $48 \mathrm{~h}$ ) on potentially degradable fraction and degradability, showing enzyme effectiveness.

Andrade (2015), who studied the effect of the addition of enzymes and urea on cotton residue (composed of stem and leaves, lyter, and sepals, boll, and stone) from the agroindustry cleaning, verified that the different enzyme levels had no effect on the soluble fraction. However, an increasing linear effect was observed for the potentially degradable fraction, fraction $\mathrm{b}$ degradation rate, potential degradability, and effective degradability at 5 and $8 \% \mathrm{~h}^{-1}$. Such data are similar to those of the present study concerning enzyme action on the potentially degradable fraction and fraction $\mathrm{b}$ degradation rate. In effective degradability at 5 and $8 \% \mathrm{~h}^{-1}$, there was also an effect on soluble fractions and effective degradability at $2 \% \mathrm{~h}^{-1}$.

Normally, when low quality roughage undergoes ammonization, there is a partial solubilization of the cell wall, thus allowing the rumen microorganisms to have a greater specific surface to adhere and, consequently, to increase the material ruminal degradability (ANDRADE, 2015). Enzymes reproduce an effect similar to that of ammonia on the cell wall components, differentiating by not acting on lignin since they are cellulolytic and hemicellulolytic enzymes.

Therefore, the in vitro degradability parameters of neutral detergent fiber (NDF) (Table 2) affected 
$(\mathrm{P}<0.05)$ by the interaction between enzyme action effective degradability at the rate of $8 \%$ per hour, times and enzyme levels were found to be only and colonization time.

Table 2. Mean parameters of in vitro ruminal degradability on coffee husk NDF.

\begin{tabular}{|c|c|c|c|c|c|c|c|c|c|}
\hline \multirow{2}{*}{$\begin{array}{c}\text { ENZYME } \\
\text { ACTION } \\
\text { TIME } \\
\end{array}$} & \multicolumn{5}{|c|}{ ENZYME } & \multirow{2}{*}{ MEANS } & \multirow{2}{*}{ CV $(\%)$} & \multirow{2}{*}{ EQUATION } & \multirow[b]{2}{*}{$\mathbf{R}^{2}$} \\
\hline & $\mathbf{T}$ & 1.5 & 3.0 & 4.5 & 6.0 & & & & \\
\hline & \multicolumn{9}{|c|}{$\mathrm{B}^{1}(\%)$} \\
\hline 24 & \multirow{3}{*}{59.0} & 56.9 & 58.4 & 55.3 & 55.0 & $56.4 \mathrm{a}$ & \multirow{3}{*}{4.33} & \multirow{3}{*}{ NS } & \multirow{3}{*}{-} \\
\hline 48 & & 53.7 & $51.2^{*}$ & 53.8 & 54.6 & $53.3 b$ & & & \\
\hline \multirow[t]{2}{*}{ Mean } & & 55.3 & 54.8 & 54.5 & 54.8 & 54.9 & & & \\
\hline & \multicolumn{9}{|c|}{$C^{2}\left(\% . h^{-1}\right)$} \\
\hline 24 & \multirow{3}{*}{0.04} & 0.04 & 0.03 & 0.04 & 0.03 & $0.04 \mathrm{~b}$ & \multirow{3}{*}{9.56} & \multirow{3}{*}{$y=0.0575-0.0038 x$} & \multirow{3}{*}{0.90} \\
\hline 48 & & 0.04 & 0.03 & 0.03 & 0.02 & $0.03 a$ & & & \\
\hline \multirow[t]{2}{*}{ Mean } & & 0.04 & 0.03 & 0.04 & 0.03 & 0.04 & & & \\
\hline & \multicolumn{9}{|c|}{$\mathbf{I}^{3}(\%)$} \\
\hline 24 & \multirow{3}{*}{40.9} & 43.0 & 41.6 & 44.7 & 44.9 & $43.6 \mathrm{~b}$ & \multirow{3}{*}{5.27} & \multirow{3}{*}{ NS } & \multirow{3}{*}{-} \\
\hline 48 & & 46.3 & $48.8^{*}$ & 46.2 & 45.4 & $46.7 \mathrm{a}$ & & & \\
\hline \multirow[t]{2}{*}{ Mean } & & 44.7 & 45.2 & 45.4 & 45.2 & 45.1 & & & \\
\hline & \multicolumn{9}{|c|}{ ED $^{4} 2 \% . h^{-1}(\%)$} \\
\hline 24 & \multirow{3}{*}{31.2} & 31.3 & 33.4 & 34.4 & 36.6 & $33.9 \mathrm{a}$ & \multirow{3}{*}{7.26} & \multirow{3}{*}{$y=28.62+0.93 x$} & \multirow{3}{*}{0.78} \\
\hline 48 & & 27.3 & 30.6 & 33.2 & 30.0 & $30.2 b$ & & & \\
\hline \multirow[t]{2}{*}{ Mean } & & 29.3 & 32.0 & 33.8 & 33.3 & 32.0 & & & \\
\hline & & & & & $E^{4} 5$ & $\% . h^{-1}(\%)$ & & & \\
\hline 24 & & 28.3 & 31.1 & 32.6 & $36.8^{*}$ & $32.2 \mathrm{a}$ & & & \\
\hline 48 & 28.5 & 23.9 & 29.8 & 32.6 & 28.7 & $28.7 \mathrm{~b}$ & 9.01 & $y=24.95+1.47 x$ & 0.84 \\
\hline Mean & & 26.1 & 30.5 & 32.6 & 32.8 & 30.5 & & & \\
\hline & & & & & $E^{4} 8$ & $\% . h^{-1}(\%)$ & & & \\
\hline 24 & & $25.7 \mathrm{a}$ & $29.0 \mathrm{a}$ & $30.9 \mathrm{a}$ & $30.7 \mathrm{a}^{*}$ & - & & $y=21.7+2.4 x$ & 0.94 \\
\hline 48 & 26.1 & $20.9 \mathrm{a}$ & $29.0 \mathrm{a}$ & $32.0 \mathrm{a}$ & $27.5 b$ & - & 11.15 & $\begin{array}{c}\mathrm{y}=25.87+ \\
12.05 \mathrm{x}-1.4 \mathrm{x}^{2}\end{array}$ & 0.99 \\
\hline & & & & & Coloniz: & tion time ( & & & \\
\hline 24 & & $3.3 \mathrm{a}$ & $2.3 \mathrm{a}$ & $1.8 \mathrm{a}$ & $0.1 b^{*}$ & - & & $y=9.5-0.72 x$ & \\
\hline 48 & 3.35 & $4.4 \mathrm{a}$ & $0.9 \mathrm{a}$ & $0.6 \mathrm{a}$ & $1.5 \mathrm{a}$ & - & 86.36 & $y=9.6-4.29 x$ & 0.97 \\
\hline
\end{tabular}

${ }^{1}$ potentially degradable fraction; ${ }^{2}$ fraction degradation rate b; ${ }^{3}$ indigestible fraction; ${ }^{4}$ effective degradability. Means of enzymatic action times followed by the same lowercase letter in the same column do not differ by the F-test at $5 \%$ probability. Means followed by $*$ differ from the control (material without enzymatic treatment) by the Dunnett test at $5 \%$ probability.

In "ED" at $8 \% \mathrm{~h}^{-1}$, although there was interaction, there were no differences between the action times for enzyme doses. As for enzymatic action, there was an increasing linear effect $(\mathrm{P}<0.05)$ of enzymes at time $24 \mathrm{~h}$, with every $1 \%$ enzyme increasing 2.4 percentage points of this fraction degradation. At time $48 \mathrm{~h}$, enzymes behaved with quadratic effect, with a maximum point at $4.29 \%$ enzyme addition, and enzymes were observed to behave better at time 24h. For colonization time, there were significant differences between the times in enzyme doses only for the level of $6 \%$ enzymes, with values higher at $48 \mathrm{~h}$. Enzymes showed decreasing linear effects $(\mathrm{P}<0.05)$, and for each $1 \%$ enzymes, there 
was a decrease of 0.72 and 4.29 percentage units of colonization time at times $24 \mathrm{~h}$ and $48 \mathrm{~h}$, respectively.

Yang et al. (1999) stated that the addition of fibrolytic enzymes promotes an increase in the colonization of ruminal microbiota since the presence of cellulases in the ruminal content favored bacterial adhesion to the cellulose. In the present study, the reduction of colonization time was probably due to the greater number of microorganisms acting on the material, which corroborates with the author aforementioned.

The regression equation for fraction "b" was non-significant for $24 \mathrm{~h}$ and $48 \mathrm{~h}$. The regression equation for the indigestible fraction "I" was nonsignificant for the mean of times ( $24 \mathrm{~h}$ and $48 \mathrm{~h}$ ).

There was a decreasing linear effect for the "C" fraction, for every $1 \%$ enzyme added, degradation decreased by 0.0038 percentage units. Also, there was a positive linear effect for "ED" at 2 and 5\%, in which each $1 \%$ enzyme addition promoted an increase of 0.93 and 1.47 units, respectively.

There was a difference $(\mathrm{P}<0.05)$ between enzyme action times ( $24 \mathrm{~h}$ and $48 \mathrm{~h}$ ) for fraction " $\mathrm{b}$ ", coefficient "C", fraction "I", and "ED" at 2 and 5\% $\mathrm{h}^{-1}$. There was an increase in the indigestible fraction after $48 \mathrm{~h}$, as well as an increase of the potentially degradable fraction " $b$ ", degradation rate of fraction b "c", and effective degradability "ED" at 2 and 5\%, which is desirable and demonstrates that the time of $24 \mathrm{~h}$ is the most adequate for enzymatic action.

Regarding NDF potentially degradable fraction (b), the addition of 3\% enzyme differed from the control $(\mathrm{P}<0.05)$ after $48 \mathrm{~h}$. There were no differences $(\mathrm{P}<0.05)$ between the control treatment and the others for the degradation rate of fraction $b$ (c). For the indigestible fraction, only the treatment of $3 \%$ enzymes at time $48 \mathrm{~h}$ differed from the control $(\mathrm{P}<0.05)$.
There were no differences $(\mathrm{P}<0.05)$ between the control treatment and the others for effective degradability at $2 \% \mathrm{~h}^{-1}$ (ED 2\%). As for effective degradability at 5 and $8 \% \mathrm{~h}^{-1}$ (ED5 and $8 \%$ ), as well as for colonization time, the level of $6 \%$ enzymes at time $24 \mathrm{~h}$ differed $(\mathrm{P}<0.05)$ from the control.

According to figure 2, there was a reduction of the NDF fraction and, consequently, a greater degradation in the enzyme level $3 \%$ at the time of $24 \mathrm{~h}$. Considering that the shorter the colonization time, the faster the ruminal microbiota will degrade the feed (ANDRADE, 2015), then feeds that have high fraction "I" content require a longer time for the action of ruminal microbiota. Based on this assertion, it is necessary to use additives that can improve the digestibility of this indigestible fraction.

Martins et al. (2008) found that there was an increase in the PD of NDF $(p<0.06)$ and hemicellulose with the addition of enzymes for rice straw. This result evidences the effect of exogenous enzymes, which allowed a greater permanence of the microorganisms on the fiber, increasing the potential degradability of the fibrous fraction of this roughage.

Except for "ED" at 2 and $5 \% \mathrm{~h}^{-1}$ (Table 3), there was no interaction $(\mathrm{P}>0.05)$ between the treatments enzymatic action times and fibrolytic enzyme levels for the other in vitro degradability parameters of the fiber in acid detergent. For "ED" at 2 and 5\% $\mathrm{h}^{-1}$, although there was interaction, there were no significant differences between the times for all enzyme doses. Both regression equations were non-significant for time $24 \mathrm{~h}$; however, there was a quadratic effect for time $48 \mathrm{~h}$, whose maximum point was at both 4.10 and $4.08 \%$ enzyme addition, respectively. 
Figure 2. Diagram of in vitro ruminal degradation on coffee husk NDF treated with exogenous fibrolytic enzymes.

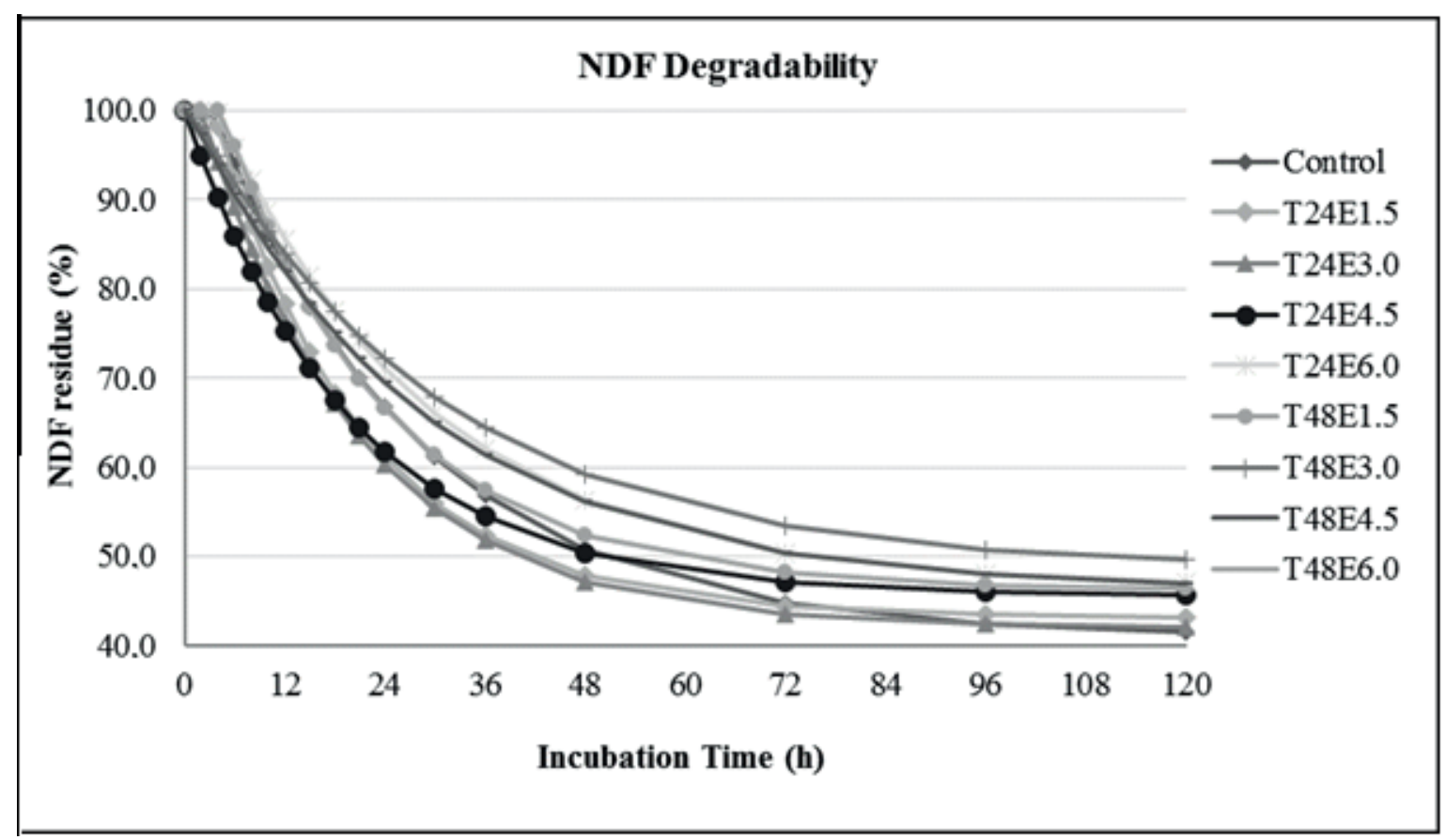

Table 3. Mean parameters of in vitro ruminal degradability on coffee husk ADF.

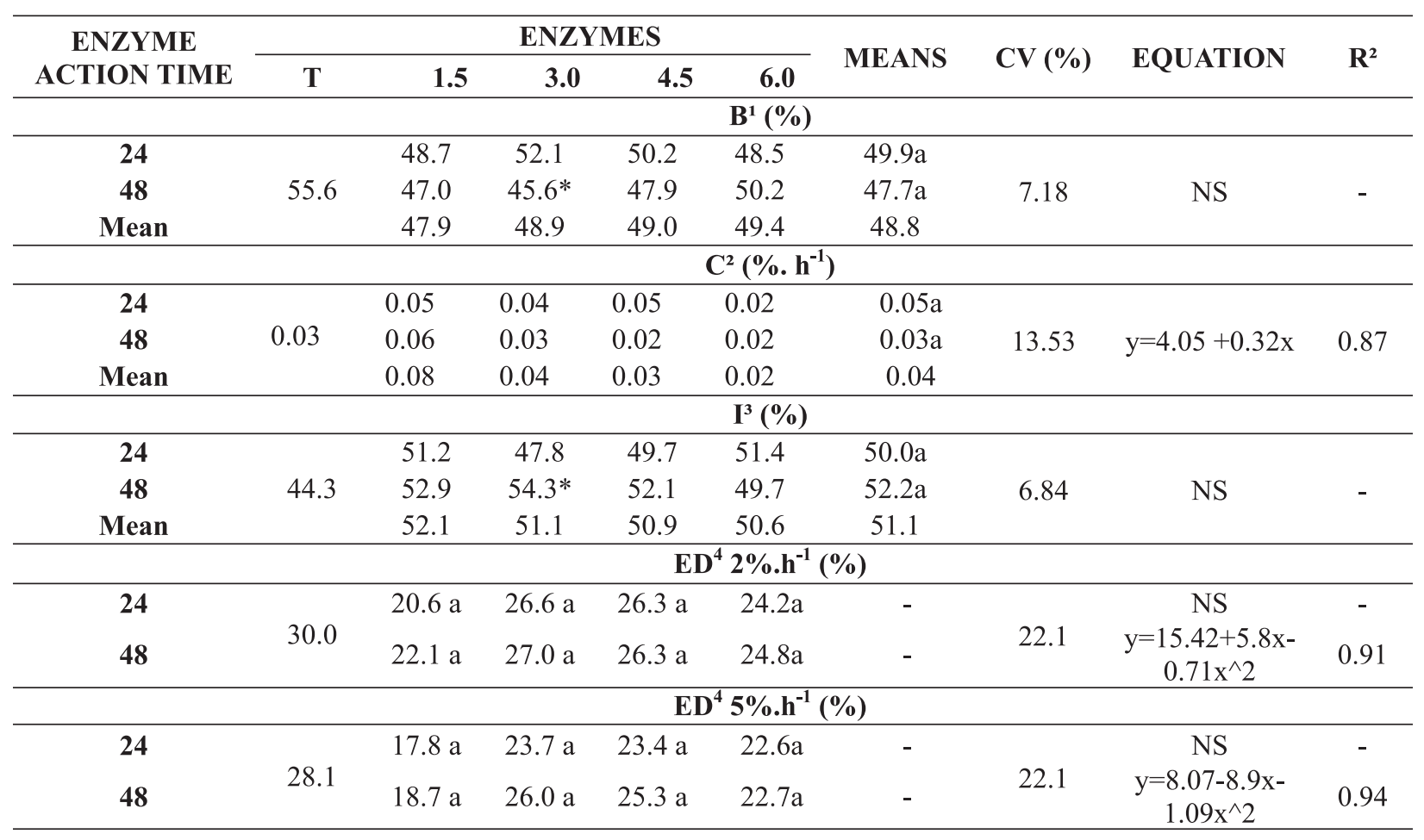


Continuation...

\begin{tabular}{|c|c|c|c|c|c|c|c|c|c|}
\hline \multicolumn{10}{|c|}{$\mathrm{ED}^{4} 5 \% . \mathrm{h}^{-1}(\%)$} \\
\hline 24 & \multirow[b]{2}{*}{28.1} & $17.8 \mathrm{a}$ & $23.7 \mathrm{a}$ & $23.4 \mathrm{a}$ & $22.6 a$ & - & \multirow[b]{2}{*}{22.1} & NS & - \\
\hline 48 & & $18.7 \mathrm{a}$ & $26.0 \mathrm{a}$ & $25.3 \mathrm{a}$ & $22.7 \mathrm{a}$ & - & & $\begin{array}{c}\mathrm{y}=8.07-8.9 \mathrm{x}- \\
1.09 \mathrm{x}^{\wedge} 2\end{array}$ & 0.94 \\
\hline \multicolumn{10}{|c|}{$E^{4} 8 \% . h^{-1}(\%)$} \\
\hline 24 & & 15.5 & 21.2 & 20.8 & 21.2 & $19.7 \mathrm{a}$ & & & \\
\hline 48 & 26.4 & 15.9 & 24.9 & 24.3 & 24.3 & $21.5 \mathrm{a}$ & 27.13 & NS & - \\
\hline Mean & & 15.7 & 23.0 & 22.6 & 22.6 & 20.6 & & & \\
\hline \multicolumn{10}{|c|}{ Colonization time (h) } \\
\hline 24 & & 5.0 & 4.0 & 4.1 & 2.9 & $4.0 \mathrm{a}$ & & & \\
\hline 48 & 2.6 & 5.6 & 1.5 & 1.4 & 3.0 & $2.9 \mathrm{a}$ & 22.09 & NS & - \\
\hline Mean & & 5.3 & 2.8 & 2.8 & 2.9 & 3.45 & & & \\
\hline
\end{tabular}

${ }^{1}$ potentially degradable fraction; ${ }^{2}$ fraction degradation rate $b ;{ }^{3}$ indigestible fraction; ${ }^{4}$ effective degradability. Means of enzymatic action times followed by the same lowercase letter in the same column do not differ by the F-test at $5 \%$ probability. Means followed by $*$ differ from the control (material without enzymatic treatment) by the Dunnett test at $5 \%$ probability.

For fraction "b", "c", "I", "ED at $8 \% "$ and colonization time, there was no difference $(\mathrm{P}>0.05)$ between enzymatic action times ( 24 and $48 \mathrm{~h}$ ). For fraction " $b$ ", the enzymes in isolation showed no significant effect for 24 and $48 \mathrm{~h}$. For the "C" fraction, increased linear effects $(\mathrm{P}<0.05)$ were observed in the enzyme levels, with every $1 \%$ enzyme addition increasing the " $\mathrm{C}$ " fraction degradation rate by 0.32 percentage units. Enzymes showed no effect for the fraction "I", "ED at 8\%", and colonization time.

In the parameter potentially degradable fraction (b) and indigestible fraction (I) of the FDA, the level of 3\% enzymes at time $48 \mathrm{~h}$ differed $(\mathrm{P}<0.05)$ from the control. There were no differences $(\mathrm{P}<0.05)$ between the control treatment and the others for the degradation rate of fraction $b(c)$. There were also no differences $(\mathrm{P} \geq 0.05)$ s between the control treatment and the others for effective degradability for 2, 5, and $8 \% \mathrm{~h}^{-1}$ (ED 2, 5 and $8 \%$ ) and colonization time.

Figure 3 shows the effect of the treatments in the incubation times on the FDA degradability. There was a reduction of the FDA fraction and, consequently, a greater degradation in the treatment with $1.5 \%$ enzyme level at time $24 \mathrm{~h}$. 
Figure 3. Diagram of in vitro ruminal degradation on coffee husk ADF treated with exogenous fibrolytic enzymes

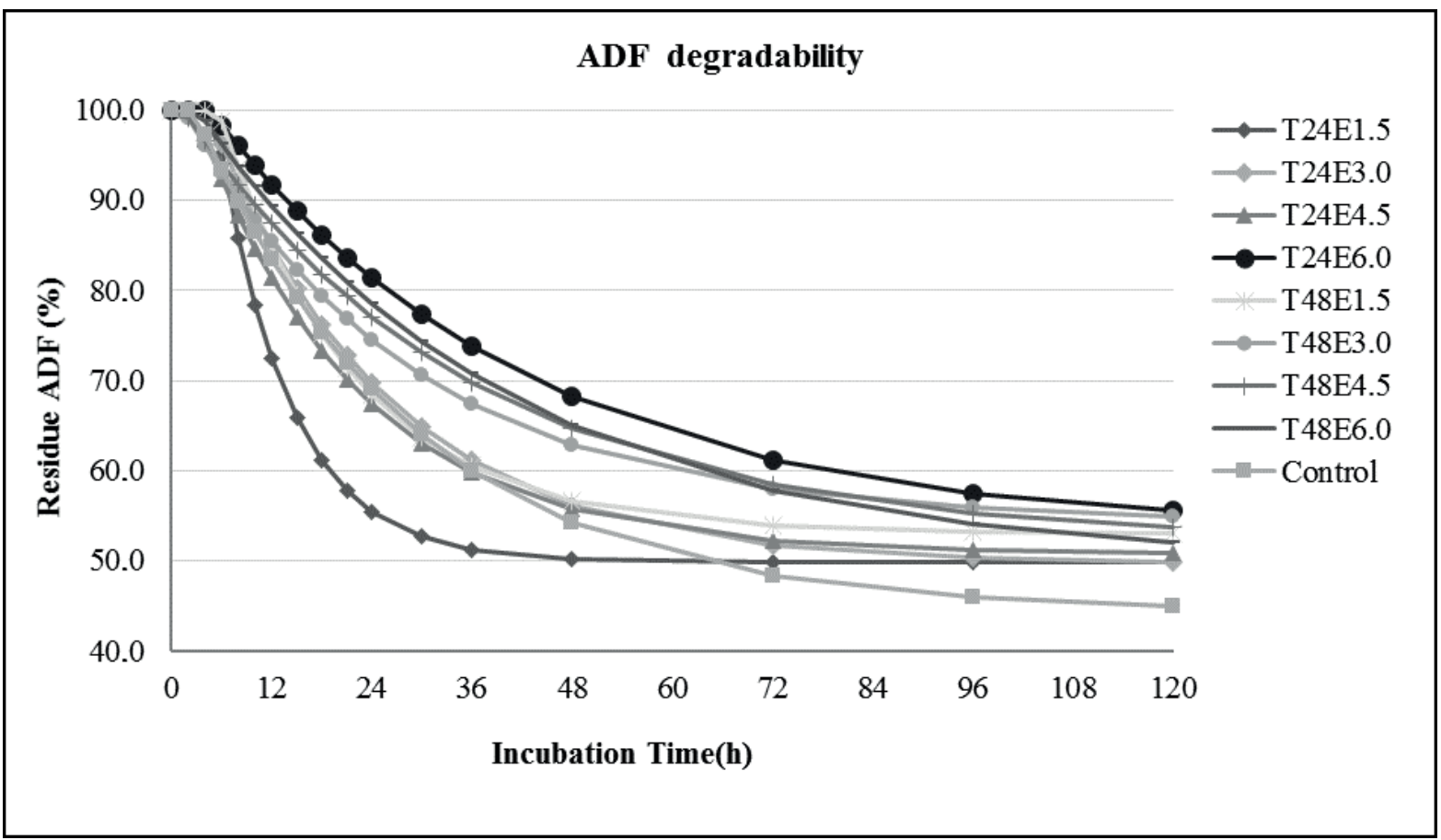

Carvalho et al. (2007), estimating the ruminal parameters of the fibrous fraction of sugarcane bagasse treated with enzymes, verified that there was a decrease in the indigestible fraction "I", and a consequent increase of the potentially degradable fraction "b", confirming the effective action of the enzymes for these parameters. Andrade (2015) obtained inferior results in similar research when compared to that of Carvalho et al. (2007). In this research, the coffee husk was used, and there was no effect of the increasing enzyme doses on fraction "b" and "I".

One of the mechanisms of digestion limitation would be the physical impediment caused by the lignin-polysaccharide binding, which causes greater resistance to chemical and enzymatic degradation (TAHERZADEH, KARIMI, 2008). The NDF indigestible fraction has the greatest effect on fiber digestion and may exceed half the total rumen NDF (MACEDO JÚNIOR et al., 2007).

\section{Conclusions}

The addition of enzymes improves the degradability of the nutritional parameters DM, NDF, and FDA, and the concentration of 3\% enzymes is the best level, with $24 \mathrm{~h}$ as the best treatment time with fibrolytic enzymes. The degradation rate of all the parameters (NDF and FDA) was reduced by increasing the treatment time of the coffee husk.

Therefore, the use of enzymes improves the digestibility of the fibrous fraction and results in the best use of the coffee husk and possibly of other agroindustrial residues. These can vary in their quality depending on the processes employed, since the purpose is to produce a feed with zootechnical properties and, of course, guarantee the environmental sustainability of the coffee processing. 


\section{References}

ALVAREZ， G.; PINOS-RODRÍGUEZ， J. M.; HERRERA, J. G.; GARCÍA, J. C.; GONZALEZ, S. S.; BÁRCENA, R. Effects of exogenous fibrolytic enzymes on ruminal digestibility in steers fed high fiber rations. Livestock Science, Amsterdam, v. 121, n. 2-3, p. 150-154, 2009.

ANDRADE, A. P. Valor nutritivo do resíduo de algodoeira tratado com ureia e enzimas fibrolíticas. 2015. Tese (Doutorado em Zootecnia, Área de Concentração em Produção de Ruminantes) - Universidade Estadual do Sudoeste da Bahia, Itapetinga.

ANKOM TECHNOLOGY. In vitro true digestibility using the DAISYII Incubator. Macedon, NY: Ankom Technology Corporation, 2010. Available at: <http:// www.ankom.com>. Accessed at: 15 july 2015.

CARVALHO, G. G. P.; PIRES, A. J. V.; GARCIA, R.; SILVA, R. R.; MENDES, F. B. L.; PINHEIRO, A. A.; SOUZA, D. R. Degradabilidade in situ da matéria seca e da fração fibrosa do bagaço de cana-de-açúcar tratado com uréia. Ciência Animal Brasileira, Itapetinga, v. 8, n. 3, p. 447-455, 2007.

COMPANHIA NACIONAL DE ABASTECIMENTO CONAB. Acompanhamento da safra brasileira de café. Terceiro levantamento. Brasília, v. 1, n. 3, p. 1-59, set. 2014. Available at: <http://www.sapc.embrapa. br/ arquivos/consorcio/levantamento/2014-levantamentode-safra-3.pdf $>$. Accessed at: 18 mar. 2015.

KRUEGER, N. A.; ADESOGAN, A. T.; STAPLES, C. R.; KRUEGER, W. K.; KIM, S. C.; LITTELL, R. C.; SOLLENBERGER, L. E. Effect of method of applying fibrolytic enzymes or ammonia to Bermuda grass hay on feed intake, digestion, and growth of beef steers. Journal of Animal Science, Champaign, v. 86, n. 4, p. 882-889, 2008 .

LANA, R. P. Nutrição e alimentação animal: mitos e realidades. 2. ed. Viçosa, MG: Universidade Federal de Viçosa, 2007. 344 p.

LOPES, L. S.; LADEIRA, M. M.; MACHADO NETO, O. R.; SILVEIRA, A. R. M. C.; REIS, R. P.; CAMPOS, F. Viabilidade econômica da terminação de novilhos Nelore e Red Norte em confinamento na região de Lavras, MG. Ciência e Agrotecnologia, Lavras, v. 35, n. 4, p. 774-780, jul./ago. 2011.

MACEDO JÚNIOR, G. L. Qualidade da fibra para a dieta de ruminantes. Ciência Animal, Fortaleza, v. 17, n. 1, p. 7-17, 2007.

MALTA, M. R.; FASSIO, L. O.; SILVA, M. M.; LIMA, P. M.; CHAGAS, R. M. R.; BARCELOS, A. F.
Composição bromatológica e fatores antinutricionais de silagens produzidas com subprodutos do processamento do café. Revista Brasileira de Agropecuária Sustentável, Viçosa, v. 3, n. 2, p. 31-38, dez. 2013.

MARTINS, A. S.; VIEIRA, P. F.; BERCHIELLI, T. T.; PRADO, I. N. Degradação ruminal da silagem de milho e da palha de arroz utilizando enzimas fibrolíticas exógenas. Acta Scientarum Animal Sciences, Maringá, v. 30, n. 4, p. 435-442, 2008

MARTINS, A. S.; VIEIRA, P. F.; BERCHIELLI, T. T.; PRADO, I. N.; LEMPP, B.; PAULA, M. C. Degradabilidade in situ e observações microscópicas de volumosos em bovinos suplementados com enzimas fibrolíticas exógenas. Revista Brasileira de Zootecnia, Viçosa, MG, v. 36, n. 6, p. 1927-1936, 2007.

MATOS, A. T. Tratamento de resíduos na pós-colheita do café. In: BORÉM, F. M. (Ed.). Pós-colheita do café. Lavras: Editora UFLA, 2008. p. 161-201.

MATOS, A. T.; EUSTÁQUIO JÚNIOR, V.; PEREIRA, P. A.; MATOS, M. P. Tratamento da água para reuso no descascamento/despolpa dos frutos do cafeeiro. Engenharia na Agricultura, Viçosa, MG, v. 15, n. 2, p. 173-178, abr./jun. 2007.

MATOS, A. T.; MAGALHÃES, M.; FUKUNAGA, F. Remoção de sólidos em suspensão na água residuária da despolpa de frutos do cafeeiro em filtros constituídos por pergaminho de grãos de café submetido a compressões. Engenharia Agrícola, Jaboticabal, v. 26, n. 2, p. 610-616, maio/ago. 2006.

McDONALD, I. A revised model for the estimation of protein degradability in the rumen. Journal of Agricultural Science, Toronto, v. 96, n. 1, p. 251-252, 1981.

MENDES, G. A.; ROCHA JÚNIOR, V. R.; RUAS, J. R. M.; PEREIRA, M. E. G.; VIEIRA E SILVA, F.; CALDEIRA, L. A.; COSTA, M. D.; ALVES, D. D.; AGUIAR, A. C. R. Substituição da silagem de sorgo por silagem de capim-marandu: consumo, digestibilidade e ganho de peso. Revista Brasileira de Ciência Veterinária, Niterói, v. 21, n. 1, p. 44-52, jan./mar. 2014.

MERTENS, D. R.; LOFTEN, J. R. The effect of starch on forage fiber digestion kinetics in vitro. Journal of Dairy Science, Madison, v. 63, n. 9, p. 1437-1446, 1980.

MILLER, G. L. Use of dinitrosalicilic and reagent for determination of reducing sugar. Analytical Chemistry, Washington, v. 31, n. 3, p. 426-428, 1959.

NUNES, H.; ZANINE, A. M.; MACHADO, T. M. M.; CARVALHO, F. C. Alimentos alternativos na dieta dos ovinos. Archivos Latinoamericanos de Producción Animal, Mayaguez, v. 15, n. 4, p. 141-151, 2007. 
OLIVEIRA, F. M. Hidrólise enzimática do bagaço de cana-de-açúcar pré-tratado com ureia. 2011. Tese (Doutorado em Zootecnia) - Universidade Estadual do Sudoeste da Bahia, Itapetinga.

ORSKOV, E. R.; MCDONALD, I. The estimation of protein degradability in the rumen from incubation measurements weighted according to rate of passage. Journal Agricultural Science, Toronto, v. 92, n. 1, p. 499503, 1979.

RECH, C. L. S.; RECH, J. L.; PIRES, A. J. V.; NUNES, G. S.; FIGUEIREDO, M. P.; XAVIER, E. G.; PINO, F. A. B.; ROLL, V. F. B.; AGUIAR, L. V.; MEIRA, A. N.; COSTA, L. S. Manual prático de análises de alimentos para animais de interesse zootécnico. Vitória da Conquista: Edições UESB, 2010. v. 500, 152 p.

RIGUEIRA, R. J. A.; LACERDA FILHO, A. F.; MATOS, A. T.; DONZELES, S. M. L.; PALACIN, J. J. F. Alteração nas características físicas, químicas e bioquímicas da água no processo de lavagem, despolpa e desmucilagem de frutos do cafeeiro. Engenharia na Agricultura, Viçosa, MG, v. 18, n. 2, p. 131-139, mar./abr. 2010.

ROCHA, F. C.; GARCIA, R.; FREITAS, A. W. P.; SOUZA, A. L.; GOBBI, K. F.; VALADARES FILHO, S. C.; TONUCCI, R. G.; ROCHA, G. C. Casca de café em dietas para vacas em lactação: consumo, digestibilidade, produção e composição de leite. Revista Brasileira de Zootecnia, Viçosa, MG, v. 35, n. 5, p. 2163-2171, sept./ oct. 2006.

SANTOS, L. Utilização de resíduos agroindustriais para produção de Amiloglucosidase por Aspergillus awamori. Revista Brasileira de Tecnologia Agroindustrial, Ponta
Grossa, v. 6, n. 1, p. 655-664, 2012.

SILVA, F. A. S.; AZEVEDO, C. A. V. The Assistat Software Version 7.7 and its use in the analysis of experimental data. Afr. J. Agric. Res, Nairobi, v. 11, n. 39, p. 3733-3740, 2016.

SOUZA, A. L.; GARCIA, R.; BERNARDINO, F. S.; CAMPOS, J. M. S.; VALADARES FILHO, S. C.; CABRAL, L. S.; GOBBI, K. F. Casca de café em dietas para novilhas leiteiras: consumo, digestibilidade e desempenho. Revista Brasileira de Zootecnia, Viçosa, MG, v. 35, n. 3, p. 921-927, 2006.

STATISTICAL ANALYSIS SYSTEM INSTITUTE SAS. User's Guide. Software, version 9.1.3 Cary: SAS Institute, 2002.

TAHERZADEH, M. J.; KARIMI, K. Pretreatment of lignocellulosic wastes to improve ethanol and biogas production: A Review. Journal Molecular Science, Basel, v. 9, n. 9, p. 1621-1651, 2008.

VAN SOEST, P. J. Nutritional ecology of the ruminant. Ithaca: Cornell University Press, 1994. 476 p.

YANG, W. Z.; BEAUCHEMIN, K. A.; RODE, L. M. Effects of an enzyme feed additive on extent of digestion and milk production of lactating dairy cows. Journal of Dairy Science, Madison, v. 82, n. 2, p. 391-403, 1999.

YOSHIOKA, H.; CHAVANICH, S.; NILUBOL, N.; HAYASHIDA, S. Producion and characterization of thermostable xylanase from Talaromyces byssochlamydoides YH-50. Agricultural and Biological Chemistry, Tokyo, v. 45, n. 3, p. 579-586, 1981. 